\title{
The Leadership of Kyai: A Descriptive Study
}

\author{
Adhe Kusuma Pertiwi \\ Department of Educational Administration \\ State University of Malang, Indonesia \\ adhe4555@gmail.com
}

\author{
Sinta Septia Anggra Cahyani \\ Department of Educational Administration \\ State University of Malang, Indonesia \\ sinta.septia1995@gmail.com
}

\author{
Risma Chulashotud Diana \\ Department of Educational Technology \\ State University of Malang, Indonesia \\ risma.reynaldo@gmail.com
}

\author{
Imam Gunawan \\ Department of Educational Administration \\ State University of Malang, Indonesia \\ imam.gunawan@fip.um.ac.id
}

\begin{abstract}
The purpose of this research is to know the characteristics of value-based leadership and ethics in Pondok Pesantren Sabilurrosyad and to describe Kyai interaction with santri in value and ethical planting process. The method used in this research is qualitative with the type of the symbolic interaction research. Data collection techniques are conducted through interviews, observations, and documentation. Data analysis with interactive model Miles, et al., (2013), namely: data reduction, data presentation, and verification. The research was conducted at Pondok Pesantren Sabilurrosyad Karangbesuki Klojen Malang City East Java Indonesia. The results showed that the characteristics of kyai leadership in instilling values and ethics in Pondok Pesantren Sabilurrosyad are: (1) kyai not only governing or advising the santri but giving examples of direct action; (2) the kyai is not excessive and appreciates the sustenance given by Allah; (3) the kyai in making the decision to prioritize advantage and goodness is not only viewed from one side; and (4) kyai regard santri as their own sons and daughters so that there is no distance in interacting.
\end{abstract}

Keywords: leadership, kyai, value, ethics

\section{INTRODUCTION}

Leadership is the art of influencing others to achieve certain goals. Leadership is an activity that influences others in order for the person to cooperate (collaborate and elaborate on its potential) to achieve the stated goals (Wahab and Umiarso, 2011; Gunawan, 2017). One of the success factors of an organization lies the role of leader. Leaders become barometers of group success in the planning, implementation, motivation, and supervision process so as to achieve common goals in groups (Gunawan, 2016a; Gunawan and Sulistyoningrum, 2013). Because of the very importance of the leader's role, so leaders are considered as role models for their members. Each leader of course has different styles, not least in pondok pesantren.

Pondok Pesantren is an educational institution with traditional Islamic education system (Zainuddin and Mustaqim, 2008). The famous leader in pesantren is more known as Kyai. Kyai becomes a patron for the surrounding community, especially regarding the main personality and the kyai plays more role than just a teacher (Bruinessen, 2005; Gunawan and Palupi, 2012). The giving of kyai title is not for just anyone, but especially for people who have the advantage of science and charity that is not owned by people and the many support from pesantren community. Kyai is a highly respected figure and an example for his santri. The interaction that exists in pesantren is different from the existing interaction in the school in general.

The interaction between kyai and santri in the boarding school is more deeply intertwined. Many santri are competing to seek the blessing of a kyai by doing little things that make kyai feel happy. While the interaction that occurs in schools between principals and learners tend to be limited by position, so that learners rarely interact with the principal. This affects the implantation of values and ethics to learners. The cultivation of values and ethics to students in public schools is common through Islamic Religious Education, but planting is not maximal, due to time constraints and less intense interaction. While the planting of values and ethics in boarding schools more intense, because kyai have a greater opportunity in instilling values and ethics because of the environmental conditions that strongly support it.

\section{METHODS}

The type of research used in this study is the symbolic interaction. Symbolic interaction is a way of thinking about individuals and society interacting (Ulfatin, 2015). The way of thinking in this research emphasizes on the interaction between kyai and santri. The approach used in this study is a qualitative approach. Researchers explore the events that occur in the field naturally. The research location is at Pondok Pesantren Sabilurrosyad Karangbesuki Klojen Malang City East Java Indonesia. Researchers use several informants to complete the data source, namely: male students, female students, santri son, and santri daughter. Data collection using three techniques, namely: interview techniques, observation techniques, and documentation techniques.

Researchers are directly involved in the process of data collection because researchers are key instruments. This is evidenced by the intensity of the researchers to observe activities in boarding schools Syabilurrosyad involving interaction kyai and santri. In addition, researchers strengthen the data needed through interview activities with various informants, 
namely: (1) santri cottage daughter; (2) caretaker of the santri daughter; (3) santri cottage sons; (4) caretaker of the men's cottage; and (5) ustad.

Data processing in this research is done by way of classifying or categorizing data based on several themes according to the focus of his research (Gunawan, 2013). The analytical technique used in this research is descriptive analysis technique where this technique will parse the results of interviews and findings of documentation and behavior that can be observed from the people who researched and then compiled in written form with an informal language that is easily understood by others. Researchers use data analysis process from Miles, et al., (2013) which consists of: data reduction, data presentation, and verification.

\section{RESULTS}

Kyai in Pondok Pesantren Syabilurrosyad there are three, namely Kyai Marzuki Mustamar, Kyai Warsito, and Kyai Abdul Aziz. The main subject of this research is the leadership of Kyai Marzuki Mustamar as the main kyai and founder of Pondok Pesantren Syabilurrosyad Malang. The santri used to call Kyai Marzuki Mustamar as "Abah". Implementation of value and ethics by kyai Pondok Pesantren Syabilurrosyad Malang is done through direct interaction with santri. These interactions give birth to leadership traits that emphasize value and ethics. The characteristics of kyai leadership that the research findings are:

1. Kyai not only governs or advises the santri but gives examples of direct action

Kyai is a role model which means that kyai is a role model in santri behaves. In every activity at the boarding school Abah tried to give "wejangan" to each santrinya to be useful in society. The wejangan is an advice. The advice given by Abah is not only verbal, but Abah gives a real example in everyday life. What he says is always manifested in concrete action. This is supported by the following interviews:

“... Terus juga sama yang dikatakan oleh tadi para temen-temen tadi yang sudah diwawancara beliau itu lebih ke bukan ngomong, bukan mendawuhi tapi lebih ke real-nya. Jadi beliau itu lebih mencontohkan gitu, ya jadi kita itu modeling kepada beliau, jadi apa yang beliau itu yang menjuluki itu akhlaknya yang akhlak kitab, jadi apa yang beliau kerjakan apa yang beliau lakukan itu apa yang sama seperti apa yang beliau ajarkan..." (W/PP/1/230418).

Translated is:

"... Continue also the same that was said by the previous friends who had been interviewed him is more to not talk, not to give but more to its real. So he was more modeled so, so we are modeling to him, so what he is calling it morals the morality of the book, so what he did what he did was what the same as what he taught ... "(W/PP/1/230418).
The statement means that Abah is not only advising but more on real action. So Abah exemplifies as a model in accordance with the existing morals of the book. The statement is supported by another santri statement as follows:

“... Kan ketika menerangkan apa isi kitabnya itu, contohnya isi kitabnya itu masalah kesederhanaan itu beliau menjelaskan itu santrinya oh yaya itu apa yang dijelaskan itu sama dengan yang beliau kerjakan. Jadi lebih kepada modeling seperti itu gak seng ndawuhi seng ceramah dowo ngono wes kan sekarang itu gak jaman kayak ngomong arek terus ngomongi arek terus opo jenenge iku omong panjang lebar itu malah gak di dengerin kan misalkan yang berbicara itu malah di walek, sampeyan gak iso ngelakoni kok opo meneh ngongkon kayak gitu-gitu. Jadi menyentuh dari hati ke hati kayak gitu ..." (W/PP/2/230418).

Translated is:

“... Well when explaining what the contents of his book, for example the contents of his book is a matter of simplicity that he explained that santri, that what is described is the same as he did. So it's more to modeling, as it does not give long counsel, because now it is not the time of counseling long and then not being heard, for example talking is denied, you just cannot do even tell someone else to do. So the important thing is to talk by touching the heart ..." (W/PP/2/230418).

The statement of the two santri explains that Abah in leading the santri to inculcate values and ethics is based on the book and example of Abah behavior as a model.

2. Kyai look not excessive and appreciate the sustenance given by God

In economic terms Abah Kyai is a capable person, but he is reluctant to live in luxury, the simplicity is seen from the style of dress and what is eaten every day. This is explained by the cottage management stating that:

“... Yang kedua terkait masalah kesederhanaan beliau, beliau itu walaupun keilmuannya luas tapi pacakane koyo wong deso omahan ..." (W/PP/4/080518).

Translated is:

"... The second is related to the problem of his simplicity, he is even though his knowledge is wide but his makeup is like a people) ..." (W/PP/4/080518).

Abah Kyai always look sober by not leaving the customs courtesy and neatness but not excessive in every event that he attended. He was in the daily food is not picky food because Abah really understand the favors of God and do not let the food wasted. In accordance with the statement of Abah driver. 
“... Jadi Abah itu sangat menghargai makanan, Abah paling benci kalau ada makanan yang mubadzir (terbuang sia-sia, peneliti). Dulu pernah pas ada acara Halal bi Halal kayak gini anak-anak itu masak nasinya berlebih gak dihitung undangannya itu sama Abah suruh menghabiskan sisa makanannya seтиа..." (W/SA/8072018).

Translated is:

"... So Abah is very appreciative of food, Abah most hate if there is food that mubadzir (wasted). Once upon a time there was a Halal bi Halal event (gathering), santri excess cooking rice, because not counted the number of invitations, Abah told to spend all the remaining food ..." (W/SA/8072018).

Leadership Abah Kyai emphasizes simplicity and does not waste sustenance as one form of grateful value towards the favor that God has given to man.

3. Kyai in making decisions that prioritize manifestation and goodness is widely seen not only from one side

The highest decision making in Pesantren Syabilurrosyad Malang is by Abah Kyai. Abah in making decisions not only seen from one side, but from various sides for the public interest. Decision making by Abah according to students as follows:

"Kalau setahu saya yang dipertimbangkan Abah Kyai adalah maslahati (yang terbaik, peneliti) jadi meskipun misalkan itu baik menurut fiqih (ilmu hukum Agama Islam) tetapi kalau gak maslahat (baik bagi banyak orang) itu tidak akan diambil..." (W/PP/5/100518).

"Cepet kalau ngasih solusi ya terutama yang Abah itu enak solusinya itu bukan untuk satu dua orang (W/SP/1/230418).

Translated is:

"I know Abah consideration is for the benefit, so even though it is legally good but not useful for many people, it is not taken..." (W/PP/5/100518).

"Quickly give the solution, Abah good it gives solution not for one or two people only" (W/SP/1/230418).

Decision making by Abah Kyai emphasizes the interests of all people rather than individuals, because Abah in making decisions not only see from one side.

4. Kyai regard santri as their own sons and daughters so there is no distance in interacting

The interaction between kyai and santri in Pesantren Syabilurrosyad is very close. Abah regard santri as their own son and daughter so santri do not hesitate to vent when there is problem of Abah and Umi (name of wife of Kyai). As said by Abah driver:
"Semua santri disini itu seperti anaknya Abah sendiri, saya sering dipanggil ke ndalem (rumah Abah, peneliti) saya kira ada apa ternyata sama Abah ditanya wes mangan opo durung? Lak durung ayo mangan karo aku (sudah makan apa belum? Kalo belum ayo makan bersama saya, peneliti) jadi itu makan bareng Abah jadi satu talam (nampan, peneliti) gitu terus saya juga sering dikasih uang saku" (W/SA/8072018).

\section{Translated is:}

"All santri like Abah own son, I am often called to Abah home, I guess what is it, was asked Abah: have you eaten? If not yet let's eat with me. So I ate with Abah, I was also often given an allowance" (W/SA/8072018).

The statement is supported by the statement submitted by the santri daughter as follows:

"Kyai sama santrinya saya rasa seperti itu, tetep sebagai santri tetep tawadhu' tapi beliaunya ke kami itu menganggap putraputrinya sendiri" (W/SP/1/230418).

Translated is:

"Kyai with santrinya I feel like that, as santri have to "tawadhu", Kyai consider us as his own son" (W/SP/1/230418).

Based on the statement it can be concluded that Abah Kyai considers santri as their own sons and daughters so there is no gap in instilling values and ethics to the students and their sons and daughters. Description is characteristic of Kyai's leadership in instilling values and ethics to the santri. The cultivation of values and ethics is done through the interaction of Kyai and santri. The interaction will be described as follows:

\section{Pengajian (Learning)}

Pengajian is a routine activity and should be held in Pondok Pesantren Sabilurrosyad Malang. Memorization done every day, recitation with Abah done on Tuesdays and Fridays considering Abah very busy schedule except in the month of Ramadan every day is done with Abah after ashar prayer until breaking the fast. Pengajian not only interpret the contents of the yellow book but also lectures about daily life in the community. On the sidelines of the lectures given Abah always took time to give advice to students.

"iya, dalam bentuk ngaji. Beliau nggak hanya ngaji beliau member contoh langsung. Kyak pas kita ngaos taklim muta'alim beri si tetntang cara menuntut ilmu, bagaimana beretika pada ilmu pasti beliau memberi contoh gimana harusnya santri lakukan ..." (W/PP/3/230418).

Translated is:

"Yes, in the form of recitation. Abah not only gives lessons but also gives examples. Like the compilations we studied "taklim muta'alim" which discusses how to study, 
how ethics requires science, Abah gives examples of how santri study (W/PP/3/230418).

\section{Diniyah}

Diniyah is the second activity after the pengajian. Diniyah in the mosque Pondok Pesantren Sabilurrosyad Malang every morning after dawn and after ashar. Just like the study, on the sidelines of Diniyah activities, Abah always took time to give advice to students.

\section{Sholat Berjamaah (Pray Together)}

The prayer touched is the last routine activity to be performed at Pondok Pesantren Sabilurrosyad Malang. This activity became one of the way santri to get barokah from Abah as arranging sandals Abah when doing worship in mosque. There is something unique in the implementation of the congregational prayer, when the prayer will begin when the santri is not fully assembled (O4 / A / 10052018). There are other unique things in preparation for the congregational prayer performed by kyai and santri as presented in the following interview:

"... membangunkan santri biasanya dengan tepuk tangan "ayoo rek bangun rek tangi rek" (Ayo bangun nak, peneliti) trus saat sore juga "ayoo rek ngaji rek" (ayo nak ngaji, peneliti) langsung gitu" (W/SPt/R/8052018).

Translated is:

Wake up santri usually with applause, come all santri wake up; when the afternoon too: let all students recite. Direct like that. (W / SPt / $\mathrm{R} / \mathrm{8052018)}$

The results of this interview is supported by observations made by researchers ie:

"When reminding students to pray, Abah will clap her hands three times while heading to the mosque, if santri do not come together Abah, will pat three times the sound system in the mosque" (O5/A/17052018).

The description is a series of routine activities at Pondok Pesantren Sabilurrosyad. In addition to these activities, there are other activities such as work together painting men's cottage building, cooperate cooking during Ramadan, and various activities of the race on the 1st anniversary of Muharram. In addition, researchers also found the behavior of santri to the unique kyai where when the santri visit or hospitality to Abah home when entering the house runs using knees. Referring to these findings, it can be concluded that the santri greatly respect Abah Kyai.

\section{DISCUSSION}

Since his birth on earth, man has brought the role is a leader. Leadership is a nature of God. Leadership is the process of the leader's activities to influence, direct, guide, motivate, or mobilize and build the co-operation of the person led in order to achieve the expected goal (Wiyono, 2013; Gunawan, 2016b). As a perfect being, man begins his leadership process starting from within himself. Broader leadership is defined as activities that can affect those outside of themselves, such as family, community, or country. This is as revealed in one of the contents of the hadith narrated in the book of Al-Muwaththa by Imam Malik (2016), which means:

"Every one of you is a leader and will be held accountable for his leadership. And Amir (leader) who leads the community, he will be held accountable for his leadership. And a man is the leader of his family and he will be held accountable for his leadership. A woman is the leader of her husband's estate and she will be held accountable for her leadership. A servant is a leader over his master's estate and he will be held accountable for his leadership. Then every one of you is a leader and will be held accountable for his leadership".

Leadership Kyai Marzuki Mustamar in Pondok Pesantren Sabilurrosyad Malang describes the ideal figure for a leader. This is characterized by the characteristics found at the time of researcher researching pesantren cottage, namely: (1) kyai not only ruled or advised the santri but gave an example of direct action; (2) the kyai is not excessive and appreciates the sustenance given by God; (3) the kyai in making the decision to prioritize advantage and goodness is not only viewed from one side; and (4) kyai regard santri as their own sons and daughters so that there is no distance in interacting.

The image of the leader's ideal in an Islamic perspective is: (1) to be able to control himself before controlling others; (2) have managerial skills; (3) have good relations; (4) the vision of the Qur'an; and (5) tawadhu attitude, has the nature of sidiq, amanah, fathonah, and tabliq (Subagja, 2010). Must be able to lead and control himself before leading others. The Kyai leadership found in the Pesantren Sabilurrosyad is that the kyai tend to prefer to give good examples for his santri with such santri will indirectly follow what kyai does without being told. Have good managerial skills because a leader must be selected from the best quality. The managerial ability of Kyai Marzuki in Pondok Pesantren Sabilurrosyad Malang is marked by the delegation of tasks to students who have more commitment than other students to bridge between kyai and santri, managing the cottage event, and so on.

Having a good relationship concept because the leader must be able to block the various differences that exist in the middle of society, the relationship between kyai and society certainly well established, it is indicated by the greatest support for the planting of values and ethics through pesantren. His vision is the Qur'an and his mission to uphold the truth. Kyai always explore the studies of the Quran that is done after the prayer. Have the attitude tawadhu and introspection in carrying out the mandate of God, because in principle leadership is not only to be accounted for in front of formal institutions but more important before God Almighty. Kyai's tawadhu and introspective attitude is also reflected by his simplicity 
from dressing and eating. It has the qualities of sidiq (true), trustworthy, tabligh (conveying what it is), fathonah (clever) and fully aware that God gives different abilities for everyone and receives it with gratitude and sincerity. Kyai has always been a taulad for santri and the surrounding community that signifies society and santri already believe in their intelligence and knowledge.

Kyai Marzuki Mustamar has its own charisma in leading the boarding school, so in instilling values and ethics in the santri not tended to be difficult. Charismatic type that is the holder of power in leadership because it has charismatic traits or dignity (Subagja, 2010; Gunawan, 2015). Kyai Marzuki Mustamar authority is highly respected by his santri, so the students have more awareness of the rules in the boarding school. One of the examples that some santri disclosed is that before the prayer kyai not infrequently patted his hand as a sign that he asked his santri to pray together, without preamble all santri direct prayers in congregation.

The cultivation of values and ethics in Sabilurrosyad pesantren is done by kyai, ie kyai becomes an example for santri. Kyai by being an example, then the santri will be reluctant and willingly will do the same with what kyai did. In addition to direct value and ethical planting, of course, the planting of values and ethics also through various kinds of activities, such as congregational prayers and pengajian diniyah that examines the Qur'an and the existing traditions about ethic that must be owned by humans. Therefore, kyai is important to empower all the resources owned by boarding schools (Kusumaningrum, et al., 2018).

\section{CONCLUSION}

The results of this study conclude that the characteristics of the leadership of kyai is to be a role model for santri, simple in everyday life, regard santri as their own children, and wise in making decisions. The process of cultivating values and ethics is done through the interaction of kyai and santri in all occasions such as pengajian, diniyah, and congregational prayers.

Kyai gives symbols, such as when he is angry he just silences but the santri can interpret the meaning of silence. Based on the results of these studies the characteristics of kyai leadership can be applied in the leadership of the principal in formal education. In addition, the interaction between kyai and santri is exemplary by the principal in interacting with learners so that the values and ethics to the students can run maximally like the planting of values and ethics to the students.

\section{ACKNOWLEDGEMENT}

Thank you to the Directorate General of Learning and Student Affairs, Ministry of Research, Technology and Higher Education who has funded this research in the scheme of the Student Creativity Program 2018.

\section{REFERENCES}

[1] Bruinessen, M. V. 2005. Kitab Kuning: Pesantren dan Tarekat Tradisi-tradisi Islam di Indonesia. Bandung: Mizan Press.

[2] Gunawan, I. 2013. Metode Penelitian Kualitatif: Teori dan Praktik. Jakarta: PT Bumi Aksara.

[3] Gunawan, I. 2015. Values and Ethics in Educational Leadership: An Idea of Character Building of Students. Conference Proceedings Character Education in Indonesia Concepts and Applications in Primary Schools, IKIP PGRI MADIUN, p. 1-3.

[4] Gunawan, I. 2016a. Model of Educational Leadership in the Implementation of Curriculum 2013. Proceedings The $4^{\text {th }}$ International Conference Language, Society, and Culture in Asian Contexts (LSCAC 2016) on Cultivating and Casting Asian Diversities: Empowering the Asians, State University of Malang, p. 1109-1118.

[5] Gunawan, I. 2016b. Perspectives of Pancasila: Leadership Education's Values and Ethics. Proceeding International Conferences on Education and Training, $2^{\text {nd }}$ ICET Theme: Improving the Quality of Education and Training Through Strengthening Networking, Faculty of Education State University of Malang, Published by Atlantis Press, p. 435-438.

[6] Gunawan, I. 2017. Instructional Management in Indonesia: A Case Study. Journal of Arts, Science \& Commerce, 8(1), 99-107.

[7] Gunawan, I., and Palupi, A. R. 2012. Taksonomi Bloom-Revisi Ranah Kognitif: Kerangka Landasan untuk Pembelajaran, Pengajaran, dan Penilaian. Premiere Educandum: Jurnal Pendidikan Dasar dan Pembelajaran, 2(2), 98-117.

[8] Gunawan, I., and Sulistyoningrum, R. T. 2013. Menggali Nilai-nilai Keunggulan Lokal Kesenian Reog Ponorogo Guna Mengembangkan Materi Keragaman Suku Bangsa dan Budaya pada Matapelajaran IPS Kelas IV Sekolah Dasar. Premiere Educandum: Jurnal Pendidikan Dasar dan Pembelajaran, 3(1), 50-87.

[9] Kusumaningrum, D. E., Sumarsono, R. B., and Gunawan, I. 2018. Teachers Empowerment of Pesantren-Based Junior High School East Java Province Indonesia. Journal of Social Sciences and Humanity Studies, 4(3), 29-33.

[10] Malik, I. 2016. Al-Muwaththa. Jakarta: Mizan.

[11] Miles, M. B., Huberman A. M., and Saldana, J. 2014. Qualitative Data Analysis: A Methods Sourcebook. New York: SAGE Publications, Inc.

[12] Subagja, S. 2010. Paradigma Nilai-nilai Kepemimpinan Profetik (Spirit Implementasi Model Kepemimpinan di Lembaga Pendidikan Islam). Progressiva: Jurnal Pemikiran dan Pendidikan Islam, 3(2), 23-42.

[13] Ulfatin, N. 2015. Metode Penelitian Kualitatif di Bidang Pendidikan: Teori dan Aplikasinya. Malang: Bayumedia Publishing.

[14] Wahab, A., and Umiarso. 2011. Kepemimpinan Pendidikan dan Kecerdasan Spiritual. Jogjakarta: ArRuzz Media.

[15] Wiyono, B. B. 2013. Kepemimpinan Transformasional Kepala Sekolah: Konsep, Pengukuran, dan Pengembangan. Malang: Fakultas Ilmu Pendidikan Universitas Negeri Malang.

[16] Zainuddin, M., and Mustaqim, A. 2008. Studi Kepemimpinan Islam (Telaah Normatif dan Historis). Semarang: Putra Mediatama Press.

Glossary:

\footnotetext{
: Kyai nickname

: Prayers performed in the afternoon (around $3 \mathrm{pm}-5 \mathrm{pm}$ )
} 


$\begin{array}{ll}\text { Barokah } & \begin{array}{l}\text { : The gifts of God that bring good to } \\ \text { human life }\end{array} \\ \begin{array}{l}\text { Halal bi Halal } \\ \text { Kyai }\end{array} & \text { : Gathering } \\ \begin{array}{l}\text { Pengajian } \\ \text { Pesantren }\end{array} & : \text { Learning activity in Islam } \\ & : \text { Educational institution with } \\ & \text { traditional Islamic education system } \\ \text { Pondok pesantren } & : \text { Educational institution with } \\ & \text { traditional Islamic education system, } \\ & \text { Islamic boarding school } \\ \text { Santri } & : \text { Student in pesantren } \\ \text { Taklim muta'alim } & : \text { Book that discusses the ethics of } \\ & \text { learning for students } \\ \text { Tawadhu } & : \text { Humble } \\ \text { Ustad } & : \text { Teacher in pesantren } \\ \text { Wejangan } & : \text { Advice }\end{array}$

